Mathematical Tripos, Part II, and in 1905 was elected a Fellow of Trinity. In 1903 he was lecturer in applied mathematics at University College, London, and during 1904-12 was examiner to the Board of Education. In 1912 he became principal of the College of Technology, Manchester (then called the Municipal School). On resigning from this post in 1920, he was appointed secretary of the League of Nations Union, which he served until 1938.

Maxwell Garnett was a big man. Well over $6 \mathrm{ft}$. in height and built in proportion, he was endowed with great natural gifts of body and mind, which enabled him to row in the University trial eights at Cambridge, and at the same time to gain some of the highest mathematical honours. His early original papers on "The Colours in Metal Glasses and in Metallic Films", published in the Philosophical Transactions of the Royal Society, amply show the qualities of mind of the authentic mathematical physicistmathematical power and physical insight ; these had been combined, as he said himself, with a happy flash of inspiration which came to him as he was examining some coloured wine glasses on a dining table. The wide range of his interests is indicated by these early scientific papers and his many other publications on psychology and education, particularly "Education and World Citizenship", an essay towards a science of education, a great work of 515 pages published in 1921. He used to say that much of his hard thinking while he was with the Board of Education was done while travelling to and fro on the underground railway. During 1941-44 he was chairman of the British Association Committee on Post-War University Education; its report was prefaced by Sir Richard Gregory, then president of the Association.

His excess of physical energy he worked off through his love of the mountains and the sea. A visitor to his home at Seaview was in no danger of being allowed to relax. As the steamer neared the pier, instead of the normal disembarkation he would see approaching, powerfully stroked by Garnett, a Canadian canoe into which he would be invited to lower his person and luggage, to be whisked away to a small landing stage near Garnett's house ; and early the following morning he would be expected to join his host for a swim. In his Manchester days, with the mountains and sea far away, Garnett was often to be seen before breakfast running around Victoria Park with the zest of a man training for a race. Such indeed he was, training his great abilities, guided and controlled by high Christian principles, to serve the cause of education and the human race.

He had many of the qualities of the great leader. No one who worked with him could fail to admire the zeal and devotion with which he applied himself to the task in hand, or fail to gain something positive from his example. If he appeared somewhat intolerant to a few who could not see so far ahead or keep up the pace he set, this could perhaps be explained by his own modesty, which would not allow him to admit that the energy and foresight of others might fall short of his own.

His high principles caused him to resign his principalship in 1920 when he did not see eye to eye with the Manchester Education Committee, which had decided to confine the university side of the College of Technology within limits which Garnett regarded as too narrow to meet the coming needs of the country for trained technologists. An example of his forward-looking qualities was his appointment of Murray Wrong, of Oxford, as vice- principal to help "to civilize the technical students". In recent years he no doubt followed with pleasure the rapid extensions that have been taking place and plans for further extensions. These were foreseen during his period of office, for the Manchester Guardian pointed out that "Mr. Garnett in addition to the ordinary labours of post-war reconstruction, had been the chief instrument in the collection of some $£ 130,000$ " intended to further the growth of the College.

Again, in 1938, having devoted all his powers to the ideals of the League of Nations Union, his principles compelled him to resign the secretaryship when he feared that the Union might be "used as an instrument of political propaganda".

Garnett was very happily married to Margaret Lucy, gifted, generous and warm-hearted, the second daughter of Sir Edward Poulton; she, three daughters and three sons, survive him. F. Bowman

\section{Mr. O. T. Faulkner, C.M.G.}

OdIN FAULKNER's career was one of great promise, fine achievement and deep disappointment. He distinguished himself at St. Albans School by gaining the Hertfordshire County Agricultural Scholarship and a major scholarship to Caius College, Cambridge. $\mathrm{H}_{\Theta}$ had a brilliant university career, graduating with first-class honours in the Natural Science Tripos in 1911 and obtaining the diploma in agriculture in 1912.

After two years with the Rubber Growers' Association, Malaya, he joined the Indian Agricultural Service as deputy director of agriculture, Lyallpur, Punjab.

In 1921, at the early age of thirty, he was appointed to the important post of Director of Agriculture in Nigeria, and it was in that country that he achieved fame. He clearly saw that the traditional system of shifting cultivation could not long sustain an increasing population, and observed that soil fertility had fallen to a dangerously low level in large sections of the country. He concentrated the efforts of his Department on devising means of maintaining soil fertility under permanent systems of cultivation. $\mathrm{He}_{\boldsymbol{\theta}}$ created consternation in Government circles by demanding a breathing space of ten years in which to solve this major problem. He inspired his staff with his own enthusiasm, and by patient team-work they evolved a system of mixed farming for the Northern Province and green manuring for the Southern Province.

He accepted transfer to Malaya in 1936, with some reluctance, but welcomed his appointment to the post of principal of the Imperial College of Tropical Agriculture in the West Indies in 1938. Here, he felt, was a challenge worthy of his mettle. The forthcoming visit of the West India Royal Commission appeared to offer a unique opportunity of enabling the College to fulfil its real destiny. In close collaboration with his collesgues, he drew up a long-term programme of development. The outbreak of war, in 1939, deferred indefinitely the implementation of this programme, and denied him what would have been the crowning achievement of his career.

Although Faulkner carried out his duties with efficiency and led the staff in numerous voluntary activities in furtherance of the war effort, his work had lost its savour. He retired in 1946 and spent his first winter in England helping to build the yacht, Chantek, which became the home of the 
Faulkner family, until a most unfortunate accident impaired the use of his hands and compelled him to abandon the sea and settle ashore.

Faulkner had simple tastes and detested formality. $\mathrm{He}$ was never at home in large gatherings, and his shy, modest and retiring disposition created the false impression that he was not approachable. In fact, there was nothing he relished more than a full pipe and a free and informal discussion. His wife, Mildred, gladly abandoned her distinguished career as a surgeon to share with Odin such pleasures as tennis, golf, bridge, gardening, country walks and yachting. His retirement enabled them and their sons to enjoy to the full the graceful ease and deep contentment offered only to a thoroughly united family.

C. Y. Shephard

\section{Prof. H. King}

Prof. Herbert King, professor of geography in the University of Hull, died on March 1 after a long and courageous struggle against failing health. $\mathrm{He}$ will be remembered at Hull as founder of the Department of Geography, for his devotion to University affairs, and in a wider field as a human geographer in the tradition of his old teacher, Prof. P. M. Roxby.

Herbert King was born in 1897 and educated at Wigan Grammar School, where in 1915 he was head boy and Powell Seholar. After three years war service in the Sherwood Foresters, during which he was wounded in France, he studied geography at the University of Liverpool, securing first-class honours, and was appointed successively to a University scholarship, a University fellowship, and a lectureship in geography in 1924. During this period he studied the evolution of the industrial and agricultural complex of Lancashire and Cheshire, and his published work included contributions to the "Lancastria" section of "Great Britain : Essays in Regional Geography".
In 1928 he was appointed the first lecturer in geography in the newly founded University College of Hull, and for the next fow years he taught singlehanded the entire geography syllabus for the University of London external degree examination, at the same time laying the foundations of what is now a flourishing Department with an honours sehool of nearly a hundred. Other activities during the 'thirties were the organization of the Land Utilization Survey of the East Riding, and a period as joint secretary and later recorder to Section E (Geography) of the British Association.

During the Second World War, Prof. King worked at the Board of Trade and the Ministry of Informa. tion, and on return to University life became deeply involved in the post-war expansion of the College, which included the development of a geological section, initially as a branch of his own Department. His experience involved him in much committee work, notably as chairman of the Library Committee (1947-52) and as dean of the Faculty of Science (1952-54). He was also president of the Hull Branch of the Geographical Association (1947-54).

In 1954, when the College received its charter as a University, he was appointed its first professor of geography. He spent the session 1954-55 as visiting professor in the University of Rochester, U.S.A.; soon after his return he showed signs of ill-heslth, but for the next two years, despite an obvious worsening, he willed himself to work almost to the end. Early this year, however, he beceme gravely ill, and he died at his home on March 1.

King published little, but his memorial is the Department which he built up, for many years under conditions of great financial stringency. He remains, to all who knew him, an example of absolute integrity, and of loyal devotion to the College and University which he served for thirty years. He married in 1926 Helen M. Ashcroft, who survives him.

L. F. Penny

\section{NEWS and VIEWS}

\section{Linnean Society of London : Awards}

The Council of the Linnean Society of London has nominated Sir Gavin de Beer and Dr. W. B. Turrill for the award of Linnean Gold Medals for 1958; normally, only one is awarded annually, to a botanist or zoologist alternately, but the centenary of the reading before the Linnean Society of the joint communication by Darwin and Wallace on evolution by natural selection is being marked by the presentation of two Gold Medals, to a zoologist and a botanist respectively. The presentation will be made at the anniversary meeting on May 24, 1958.

In commemoration of the centenary the Council of the Society has also nominated the following for the award of a Silver Darwin-Wallace Commemorative Medal in recognition of their outstanding contributions to our knowledge of evolution. The Medals will be presented at a special meeting of the Society to be held at the Royal Geographical Society on July 15: Dr. Edgar Anderson (U.S.A.), Prof. Maurice Caullery (France), Sir Ronald Fisher (Great Britain), Prof. C. R. Florin (Sweden), Prof. J. B. S. Haldane (Great Britain), Prof. Roger Heim (France),
Dr. John Hutchinson (Great Britain), Sir Julian Huxley (Great Britain), Dr. Ernst Mayr (U.S.A.), Prof. H. J. Muller (U.S.A.), Prof. E. Pavlovsky (U.S.S.R.), Dr. Bernhard Rensch (Germany), Dr. G. Gaylord Simpson (U.S.A.), Prof. Carl Skottsberg (Sweden), Prof. E. A. Stensiö (Sweden), Dr. H. Hamshaw Thomas (Great Britain), Prof. G. V. Turesson (Sweden), Dr. V. van Straelen (Belgium), Prof. D. M. S. Watson (Great Britain) and Dr. J. C. Willis (deceased).

\section{Metallurgy at Cambridge : $\quad$ Prof. G. W. Austin}

THE impending retirement of Prof. George Wesley Austin from the Goldsmiths' chair of metallurgy in the University of Cambridge presents an occasion for directing attention to the remarkable growth in metallurgical activity that has taken place during his occupancy of the chair. While the Department of Metallurgy has had a separate existence for many years-it was founded in 1888--the situation of Cambridge, away from the centres of the metallurgical industries, has tended to militate against any great development there in the teaching of the more practical aspects of the subject. The rapid widening 